\title{
RELIGION AS A BOND - A DELUSIVE HOPE OF POLITICS
}

\begin{abstract}
Politics is on the one hand an attempt to implement certain good, a desire for achieving agreed objectives, on the other hand - as Max Weber says - a simultaneous attempt to avoid a particular evil. If in defining the notion of politics there are references to good and evil, purpose and desire, it has to include the non-political spheres - culture, axiology, religion. Mark Lilla argues that for decades we have been aware of the great and final separation that has taken place in Western Europe between political and religious life. This awareness implies a conviction, which is obligatory today in most countries and societies, that to separate politics from religion is a great achievement. For many thinkers and politicians this is an undisputed success from which the West learns to benefit while preparing other regions of the world for such separation. Therefore it seems that modern politics should be free from religious inspiration and temptation. On the other hand, a significant number of sociologists and political scientists show the vitality of religious attitudes, proving that in its deepest essence religion is an expression of human behaviour. Each person and each community always has an element of irreducibility which is an internal defence against reducing man to "here and now", confining his world to what is useful and usable. It is our experience that a man is naturally open to transcendence. Thus, if man is ever to achieve individual and social reconciliation with himself, he will always look for rational and moral meanings. This situation creates a platform for the emergence of a completely new attitude in society and politics - attitude of seeking and pursuing spirituality in a world without religion. Increasingly, the understanding of religion manifests itself in a wide etymological sense, sociological and ethnological: religare - "to connect", "to bind", "to build community ties". Religion so understood would be a great solution to the dilemma of separation - the adoption of religion (bonds) without a doctrine, while ensuring social cohesion, strengthening the feeling of being together, maintaining a spiritual connection. Many thinkers are convinced that we cannot base social life only on fear, discipline and economy; we need a deeper and stronger foundations for Community Cohesion. But is it possible to carry out such a project at all? Is politics becoming a place for the formation of relationships, education and conservation of values, a narrative space which tells citizens what is good and right and what is wrong and inappropriate? Can it replace religion in its deepest essence - in its intimate sense of an exploration and discovery of transcendence? Will it not become a caricature of religion, and a caricature of politics, and ultimately a trap for freedom?
\end{abstract}

* This article was originally published in Polish as: J. Grzybowski, Religia jako więź - zwodnicza nadzieja polityki, Studia Philosophiae Christianae 47(2011)2, 209-229. The translation of the article into English was financed by the Ministry of Science and Higher Education of the Republic of Poland as part of the activities promoting science - Decision No. 676/P-DUN/2019 of 2 April 2019. Translation made by GROY Translations. 
Keywords: politics; religion; culture; Richard Rorty; postmodernism

1. Introduction: The inevitability of the great separation. 2. The necessity for religion. 3. Religious foundations of a liberal world. 4. Politics as a bond - a hope for solidarity. 5. Conclusions: The real power of religion - internal transformation.

\section{INTRODUCTION: THE INEVITABILITY OF THE GREAT SEPARATION}

Politics is on the one hand an attempt to implement certain good, a desire for achieving certain agreed objectives, on the other hand - as Max Weber says - a simultaneous attempt to avoid a particular evil ${ }^{1}$. If in defining the notion of politics there are references to good and evil, purpose and desire, it has to include the non-political spheres - culture, axiology, religion. This means that politics is not so much a formal-procedural discourse as an ethical-axiological one. This, of course, results from the very attempt to define politics, not as a technocratic structure, but as a relationship ${ }^{2}$. As Mark Lilla argues, that it cannot be forgotten that for decades we have been aware of the great and final separation that has taken place in Western Europe between political and religious life ${ }^{3}$. This awareness implies a conviction, which is obligatory today in most countries and societies, that to separate politics from religion is a great achievement. For many thinkers and politicians this is an undisputed success from which the West learns to benefit while preparing other regions of the world for such separation.

This tendency is not new, of course. Hugo Grotius, called the founding father of international law, already excluded God from international relations, claiming that religions are the cause of unrest, dispute and war. The idea of God and religion has been also excluded from scientific research. Many are convinced that the issue

1 See: M. Weber, Polityka jako zawód i powołanie, transl. A. Kopacki, P. Dybel, Warszawa - Kraków 1998.

2 See: M. Król, Filozofia polityczna, Kraków 2008, 130ff; J. H. H. Weiler, Chrześcijańska Europa. Konstytucyjny imperializm czy wielokulturowość, Poznań 2003, 114.

3 Cf. M. Lilla, Bezsilny Bóg. Religia, polityka i nowoczesny Zachód, transl. J. Mikos, Warszawa 2009, 62. 
of the existence or non-existence of God is no longer scientifically or metaphysically interesting ${ }^{4}$. In the early twentieth century, John Dewey, one of the key creators of the new American educational culture, argued that the pursuit of absolute ideas, the ambition to create the highest rationale and principles, only lead to authoritarian policies which are always anti-democratic. This should result in a reasonable consent to only interim and pragmatic solutions to social and political problems $s^{5}$. Thinking along the same lines, Richard Rorty expressed a specific desire: "We wish we did not have to have an opinion about God. It is not that we know that the word God is a meaningless term, or that it fulfils the function in a word play not aimed at establishing facts. We are sorry that this word is used so often", said Rorty 6 .

This desire has been largely fulfilled, but its effect is not so much the achievements of secularization as the fact that politics, not religion, takes responsibility for the space in which, until now, the Christian narrative has dominated in our civilization. In this situation, it is culture and politics in the broadest sense of the word that are faced with an attempt to gather people around an idea. This is due to the obvious fact that each community, all the more so the political one, must implement good defined in some way (values). This means that in any society (as paradoxical as it sounds), it is impossible to implement politics without "religion", i.e. without social references anchored in the arguments in favour of bonds. Thus, politics, whether we like it or not, becomes a kind of implementation of values, axiological behaviour and rules. The consequence of this is the conviction that for many people it is social and political relations, not religion, that

4 See: H. Grotius, Trzy księgi o prawie wojny i pokoju w których znajduja wyjaśnienie prawo natury i prawo narodów a także główne zasady prawa publicznego, transl. R. Bierzanek, Warszawa 1957.

5 See: J. Dewey, Philosophy and Democracy, in: The Middle Works of John Dewey 18991924, vol. 11 (1918-1919), ed. J. A. Boydston, Southem Illinois University Press 1988, 43-53.

6 Cf. R. Rorty, Konsekwencje pragmatyzmu. Eseje z lat 1972-1980, transl. C. Karkowski, Warszawa 1988, 141. 
have become, in a way, the "soul" of the modern, multicultural and multithreaded world ${ }^{7}$.

Apparently that the leading pragmatists and postmodernists of the West - to name but a few: Rorty, Vattimo, Žižek, Agamben, Bauman, Fish - share not so much the negation of God and religion but the hope and conviction that if the public and political space is deprived of religious symbolism and its narratives, it will remain empty and thus, by definition, will become better. It will not generate oppression and confrontation; on the contrary, it will manifest itself as a place of debate where the solutions better than confessional ones can be worked out $^{8}$. Disapproval of using religious arguments in the public debate is based on the conviction that theybring conversation to an end, because religions do not foresee the possibility of their own error' ${ }^{9}$ Thus, religious emblems (e.g. the cross) will change their meaning - they will be regarded as cultural gadgets, peculiar souvenirs and symbols, signs of a faith that has "emigrated" into the private sphere, thus becoming a hidden treasure to which only the trusted are allowed. A space meticulously cleared of religious symbolism is considered in this vision to be more democratic and thus able to prompt proper social behaviour on a basis other than religious. The desire to "sterilize" the public sphere from religious symbolism and confessional attitudes is thus based on the conviction and assumption that politics, devoid of religious inspiration, will create better and more lasting motivations for community life.

\section{THE NECESSITY FOR RELIGION - BONDS}

Why does this transformation seem necessary? Although, the influence of religion on political life and the construction of moral social rationale have been finally pushed out of the public sphere into the

7 Cf. T. Eagleton, Rozum, wiara i rewolucja. Refleksje nad debata o Bogu, transl. W. Usakiewicz, Kraków 2010, 147; G. Ritzer, Magiczny świat konsumpcji, transl. L. Stawowy, Warszawa 2009, 27ff.

8 Cf. R. Rorty, Filozofia a zwierciadło natury, transl. M. Szczubiałka, Warszawa 1994, 315.

9 Cf. Idem, Religion in the Public Square. A Reconsideration, Journal of Religious Ethics 31(2003), 141-149. 
private sphere, the very ethos that binds communities together is still needed in secular society. Religion as a narrative, as a sign of the confessional era has been weakened, but post-modernity failed to find a formula that would fulfil the desire for a policy that would create a good, free, just world, free from religious inspirations ${ }^{10}$. The hope that it is enough to equip a good man with tools - social and political instruments - and this will allow him to build a better world has failed. The atheistic thinker Andre Comte-Sponville, among others, is convinced that secular society, a modern world of great separation, needs a religion understood quite differently - as a great world of thoughts, symbols, gestures, customs and values. After all, no society can do without religion, just as there is no society without education, no civilization without message, no community without fidelity ${ }^{11}$.

This is confirmed by many sociologists and political scientists, whose research shows the vitality of religious attitudes, proving that in its deepest essence, religiousness is an expression of human behaviour. In spite of the secularization changes, it turns out that in every person and every community, there is always some element of irreducibility, that is, an internal defense against reducing a human to the "here and now" only, limiting their world to what is useful

10 Among other things, the consequences of May'68 are becoming less and less enthusiastic. The unstoppable decline of school and education in many Western countries began at that exact time. One of the offenses of this rush was the confusion of the teacher who educates with the master who dominates. We still have not recovered from this confusion. This was also when spontaneity was elevated to the rank of a criterion of conduct. "May'68" was not so much a revolt against capitalism as it was a feud with bourgeois forms. As a result, many people were orphaned by these forms that post-modernity abolished without offering anything in return. All areas of existence - but especially culture and education - have unfortunately been subordinated to the idea of equality. But even the enthusiasts of "Revolution'68" say that one must also want, can and know how to defend the idea of hierarchy between people, especially between a teacher and a student. Because if this order collapses, culture and education will collapse too. See: A. Finkielkraut, Wielokulturowość w Europie polega na afirmacji wszystkich tożsamości poza własna, lecture given on June 27, 2011 at the European Debates of the Centrum im. prof. Bronisław Geremek, Ośrodek Kultury Francuskiej Uniwersytetu Warszawskiego and Francuska Izba Przemysłowo-Handlowa w Polsce.

11 cf. A. Comte-Sponville, Duchowość ateistyczna. Wprowadzenie do duchowości bez Boga, transl. E. Aduszkiewicz, Warszawa 2011, 36, 46. 
and helpful, mechanical and technical ${ }^{12}$. Marek Szulakiewicz rightly notes that the good condition of religion in the 21st century is one of the most annoying problems for many. For its expected end and fall does not occur. Religion is a part of human consciousness and not, as many intellectuals and politicians thought, just a stage in history ${ }^{13}$. After all, we ourselves experience the fact that in every human, there is a natural openness to what exceeds them - to what is transcendent and what is often expressed in poetry, music or art. Therefore, if a person is to ever, in individual and social life, achieve reconciliation with themselves, they will always seek the rational and moral meaning of their existence. Sometimes this phenomenon is called the deprivatization of religion, referring to the process of the return of religious doctrine, religious values and its institutional dimensions to the scene of social life on both the normative and behavioral levels ${ }^{14}$.

In my opinion, such a situation creates a platform for the emergence of a completely new attitude, both social and political - the search and realization of spirituality in a world without religion. In a project of great separation, disconnected from confessional rations, arguments and influences, but at the same time in a space of human relationships in which one cannot live without politics (outside the community) and cannot live without bonds. Hence, contemporary atheists, satisfied with the separation of religion from politics, say at the same time - you may not believe in God and still cultivate

12 Cf. J. Mariański, Religia w społeczeństwie ponowoczesnym, Warszawa 2010, 157; J. Sochoń, Religia jako odpowiedź, Warszawa 2008, 85-93.

13 Cf. M. Szulakiewicz, Religie i religijność we współczesnej kulturze, in: Religie i religijność we współczesnym świecie. III Międzynarodowy Kongres Religioznawczy, ed. M. Szulakiewicz, Toruń 2011, 22.

14 As Casanova argues, secularization and deprivatization are social processes of historically and culturally determined character and course. In different historical periods and cultural circles, the relations between them were shaped differently and sinusoidally. Secularization and deprivatization create a theoretical framework for reflection on the legitimizing function of religion in the social world. See: J. Casanova, Deprywatyzacja religii, in: Socjologia religii Antologia tekstów, ed. W. Piwowarski, Kraków 1998; P. Michel, Polityka i religia. Wielka przemiana, transl. B. Czarnowska, Kraków 2000, 98. 
important religious traditions. It has become clear that people want to celebrate important social moments, important stages in their lives and those of their community members, to enter into some ritual, a para-religious celebration ${ }^{15}$. Every culture, including the Western culture, needs some continuity and tradition, but - in the eyes of postmodern thinkers - understood not as a religious denomination (confession, faith), but as a certain cultural code, a specific bond of both social and political life. However, if this code is rooted in tradition, seeks goals and values, then the very achievement of great separation does not answer the question - what story supports people and their communities by constructing paradigms, defining values and choices? Of course, in some sense, the sociological role of religion as the universal social bond is played by the market and the capitalist economy. It is about the information market, because today it is the best commodity and the most desirable good. Halik claims that it is the media that have taken over most of the traditional roles of religion - they interpret the world, decide on the issue of truthfulness and importance, propose great symbols, lifestyle, create events and sacraments - signs of what is fleeting, mysterious, distant and invisible ${ }^{16}$.

The openness to what is transcendent and mysterious, what exceeds the everyday, relative dimension of human existence, what does not fit into our world, is to some extent the basis and source of religious experience. However, such experiences can, especially nowadays in the age of secularization, produce a purely cultural spirituality, consciously deprived of its roots in institutional religions ${ }^{17}$. These are, on the one hand, the resources of religious culture incorporated into the political system, on the other hand, the mental acts

15 It is a kind of peculiarly understood religion without God - a democratic religion of the people, born of people, for people, by people. A religion that gives space to go beyond itself, but that space is not eschatological. Such a proposal does not provide the content in transcendence, but ensures well-being, fulfilment here on earth, in the present. Cf. M. Lilla, Bezsilny Bóg. Religia, polityka i nowoczesny Zachód, op. cit., 230.

16 Cf. T. Halik, Europa pomiędzy laickością a chrześcijaństwem, Więź (2011)2-3, 127.

17 Cf. M. Szulakiewicz, Religia i czas, Toruń 2008, 134-136. 
of community, traditions, types of habitual behaviour and related ethos. They become (especially for those who describe themselves as non-believers, agnostics, atheists) a platform for creating motivation for human attitudes in a pluralistic, migratory, heterogeneous, changeable and hybrid world ${ }^{18}$.

All this makes secularization and its achievement manifest itself, as I have already pointed out, through the loss of religious inspirations and theses of influence on political decisions. Religious content was separated from political power structures. At the same time, however, in the experience of the West, which assimilated the idea of great separation, there is also the awareness that religion has not disappeared from public and social life ${ }^{19}$. Of course, this shape of religion is no longer based on the hard paradigms of great confessions and their institutions. It becomes a more individual and existential event. The secularization postulates should therefore be reviewed. Religion has not disappeared, but in late modernity, it plays a different social and cultural role than a few decades earlier. Nevertheless, we still need morality, community, fidelity, tradition, enthusiasm, imagination, work, loyalty to exist as a community. In the public and scientific debate, there is, therefore, a persistent conviction that the bond that will tie a pluralistic and polyphonic world together does not have to be religion, even understood as tradition, but politics. But how can spirituality and axiology be pursued in the political world without religious inspirations and influences if there is no longer a narrative in the West that would connect entire generations? After all, we no longer live in the shadow of the Christian tale of God and man.

I believe that for many of today's secular people, the answer is religion, but understood in a wide etymological sense, sociological and

18 This obviously implies a practice in which rituals, institutions and forms become the most important. Without a profound experience of transformation, religion becomes a form in itself and a goal for itself. The reason for this phenomenon is the separation of religious experience (personal involvement) from religious rituals. See: K. Dobbelaere, Sekularyzacja. Trzy poziomy analizy, transl. R. Babińska, Kraków 2008, 67ff.

19 Cf. M. Szulakiewicz, Religie i religijność we współczesnej kulturze, op. cit., 25. 
ethnological, in the meaning of the term - religare - "to connect", "to bind", "to build community ties" ${ }^{20}$. A religion defined in this way can permeate all the most important areas of life, including politics, understood as concern for the common good, building the future and making an effort to accomplish the goals set. More and more voices are being heard that a society, a nation, a state, communities necessarily qualified as democratic today, need a certain quantum of common values that will bring generations together. Without it, no society can survive or develop ${ }^{21}$.

\section{RELIGIOUS FOUNDATIONS OF A LIBERAL WORLD}

What does that mean? The Western world is clearly moving towards a transformation of civilization paradigms. It gives up religion in the public and institutional space, but at the same time offers a kind of substitute - a kind of mysteries of the state, which are understood as a spiritual legitimization, and as a point of reference for modern societies. As Szymon Wróbel says, liberalism is a weak project, above all a "metaphysically weak" project. It is dominated by the desire to avoid metaphysical obligations, but also religious and ethical attachments, discourses about the ultimate good. Paraphrasing the slogan "minimum of state", liberalism, in some way, says: minimum of metaphysics. However, against a metaphysical, ethical and religious minimum, the cultural and political proposal of the state becomes a very strong one ${ }^{22}$. Even secular thinkers such as Slavoy Žižek, Alain Badiou, Fredric Jameson can see

20 See: E. Durkheim, Elementarne formy życia religijnego. System totemiczny w Australii, transl. A. Zadrożyńska, Warszawa 1990. It was Durkheim himself, the son of a rabbi, who abandoned the confession and adopted an atheistic worldview, developed the idea of a global civil religion, writing about the "cult of man", the "religion of humanity", or the "religion of law". A key role in this secular religion was to be played by state education, aimed at bringing up citizens capable of sacrifice. See: R. A. Wallace, Ėmile Durkheim and the Civil Religion Concept, Review of Religious Research 18(1977), 287-290.

21 Cf. A. Comte-Sponville, Duchowość ateistyczna. Wprowadzenie do duchowości bez Boga, op. cit., 32.

22 Cf. S. Wróbel, Kto się boi liberalnej religii obywatelskiej?, Znak 671(2011)4, 48. 
the impact of a "theological proposal" thus formulated on politics even though they themselves, of course, have a negative opinion of $\mathrm{it}^{23}$.

The need for such social mysteries, organized by political bodies, stems from the simple and already mentioned observation that no community can be based solely on the concentration of power, compulsion and economy in the long term. The state and the rulers (those who govern cultures and civilizations) also need spiritual justification ${ }^{24}$. For many people who accept the capitalist-liberal model, culture, not religion, is a kind of quasi-sacrament of the modern world. Culture, its symbolism and content, become a kind of visible sign of an invisible (but secular) reality. Without symbolic structures that allow hope into society beyond immediate interests and temporal calculations, societies and individuals lose their orientation ${ }^{25}$. The political nature of humans is connected with their ability to speak, rationally discuss and decide on fundamental issues of social life, such as justice, rightness, courage. In this, and only in this sense, politics can be a sphere of realization of human freedom and perfection. The potential of values is realized in the sphere of what is political, where there is a possibility of an argumentative, rational, free dispute concerning basic community goods goodness, fairness, justice ${ }^{26}$. Thus, despite the diversity and polyphonic structure, the democratic society cannot function without discipline, restraint, tolerance, patience, willingness to compromise and trust $\mathrm{t}^{27}$. That is why despite the achievements of the secular community of contemporary Western countries - choice (democracy), progress, freedom, law, courage, generosity, serenity, justice - it is increasingly evident that, as

23 See: G. Jankowicz, Nowoczesne misteria państwa, Tygodnik Powszechny 48(2009), 40.

24 See: K. J. Schipperges, Religia a zeświecczone społeczeństwo. Instrumentalizacja religii w nowożytnych systemach władzy politycznej, transl. B. Floriańczyk, Communio 138(2003)6, 84.

25 Cf. T. Eagleton, Rozum, wiara i rewolucja. Refleksje nad debatą o Bogu, op. cit., 167; A. Delbanco, The Real American Dream: A Meditation on Hope, Harvard University Press 2000, 56.

26 Cf. Ł. Dominiak, Cztery koncepcje zoon politikon. Uwagi dotyczące problematyczności politycznej natury człowieka, Horyzonty Polityki 1(2010)2, 101.

27 See: K. J. Schipperges, Religia a zeświecczone społeczeństwo. Instrumentalizacja religii w nowożytnych systemach władzy politycznej, op. cit., 66. 
Comte-Sponville says, it needs religare (bond) and sacrum (sacrifice) to defend these achievements. Society and politics can do without God as a transcendent reason, but it cannot do without religion understood as a bond ${ }^{28}$. The liberal secular state lives and works effectively thanks to assumptions developed through centuries of religious narrative, which it does not establish and cannot fully guarantee. These are anthropological ways of perceiving a human, and these are never neutral in their content in regard to world view. On the contrary, they result from certain assumptions, both philosophical and theological, which at the same time imply certain conclusions concerning the shape of social and political life. Hence, the state and the law are never a pure political element, but are based on accepted (consciously or not) world views. The total neutrality of the community is therefore an illusion and even the leading liberal thinkers are aware of this ${ }^{29}$. Jürgen Habermas, who was referred to by many as the "Pope of secularism", warns against "unjustly excluding religion from the public sphere" and "cutting secular society off from the important sources of meaning" that are still hold by religious communities today. It turned out that reason is not a socially sufficient tool for ensuring solidarity in society: religious reflection is still necessary, says the German philosopher. Reflection purified by a process of critical self-reflection, which the social sciences already have done. Science itself should "keep a distance from religion without closing in on its perspective". It turns out that it is often religion, and not scientific arguments, that remains an irreplaceable protective barrier against various types of extremism: greedy market expansion, bioengineering, economic polarization ${ }^{30}$.

Even Gianni Vattimo, who cannot be accused of being a religious sympathizer, says that liberal European societies should allow

28 Cf. A. Comte-Sponville, Duchowość ateistyczna, op. cit., 34.

29 See: K. J. Schipperges, Religia a zeświecczone społeczeństwo. Instrumentalizacja religii w nowożytnych systemach władzy politycznej, op. cit., 80.

30 Cf. J. Habermas, Faith and Knowledge, in: Idem, The Future of Human Nature, Cambridge 2003, 109; J. Habermas, J. Ratzinger, The Dialectics of Secularization. On Rison and Religion, San Francisco 2005; S. Burdziej, Socjologia postsekularna?, Studia Socjologiczne 197(2010)2, 97. 
Christian symbols in the public sphere, while excluding Muslim symbols that are alien to European tradition. The cross should become a universal symbol of secular society, constituting, in a broad sense, the humanistic condition of the people of Europe ${ }^{31}$.

It turns out that the secular world of postmodern ideas, although it has deconstructed all great narratives, needs to read old religious texts to create bonds, a community of tradition, origin and moral prerogatives. Ancient religious knowledge can integrate people in common activities, giving structure and hope to the community. Religion appears here not as a confession, but as a love for the story, love for the word, for the $\operatorname{Logos}^{32}$.

\section{POLICY AS A BOND - A HOPE FOR SOLIDARITY}

The consequence, however, of such an approach to religion and its cultural role is that a privatized, non-dogmatic and soft form of religious existence, reconciled with the achievements of the modernizing Western world and recognizing its pluralistic and neutral priorities, will not fulfill its educational and moral role either. In my opinion, it is not able to create a motivational foundation for moral behaviour. That is why its role is taken over by politics establishing values and behaviours (ties as I call them) in the so called background culture. Such tendencies could be observed already in the Protestant reflection on the role of religion in politics ${ }^{33}$. Jürgen Moltmann argued that the church and religion should be dissolved, so to speak, in the state, and faith in a civic ethos. Secularization of religion was to strengthen the state and culture. This will transform religion into politics, and politics will create a space for learning ethical and civil behaviour ${ }^{34}$. Thus, religion descends, becomes

31 See: G. Vattimo, After the Christianity, Columbia University Press 2002, 101-102.

32 Cf. A. Comte-Sponville, Duchowość ateistyczna, op. cit., 35.

33 Cf. M. Marczewska-Rytko, Religia i polityka w globalizującym się świecie, Lublin 2010, 249-251.

34 Cf. J. Moltmann, Theology of hope: on the ground and the implications of a Christian eschatology, transl. J. W. Leitch, London 2002, 202-210. Of course, the first strong modern link between religion and politics, or rather the subordination of religion to politics, 
reflexive and is reconciled with the reality of the modern state, within a liberal political order. It is convenient for those in power, does not bother anyone, its arguments do not have to be present in the political debate, and at the same time gives individuals inspirations and motivations other than politics. In this way the secularization force is strengthened. The state becomes sovereign, free from such an important social factor as religion, even transforming it and later taking its place ${ }^{35}$.

Of course, the key desire of many atheistic circles to build a world with rules not determined by religious laws and principles, but purely political, independent of, for instance, Christian inspirations. In such a world, there is no need to wait for God's Messiah, all hopes are placed in the "here and now". At the same time, there is a belief in the realization of the state of justice and peace, kindness and goodness, as prerogatives that only come from immanent temporal conditions ${ }^{36}$.

A similar hope was also expressed by the aforementioned American pragmatist Richard Rorty, who claimed that there does not have to be

occurred in Hegel's philosophy, where the state was defined as a self-conscious ethical substance. It is an ethical spirit as an open, self-explanatory substance will, which thinks of itself and realizes itself, and which puts into action what it realizes, providing that it realizes at all. The state understood as an ethical community turns out to be the first - an autonomous and self-sufficient total. The state is the reality of the rational will, which has been elevated to the level of universal self-awareness. In this way it is the highest expression of the objective spirit. Hegel speaks of the state in the most sublime words. He even says that "the existence of the state is a march of God in the world". In Hegel's historical-philosophical idea, the state as an objective spirit is necessarily "divine" in a certain sense and must be treated as a divine element present on earth. And as the Absolute itself is an identity in diversity, so is the state. In the final perspective, the state is a divine idea available on earth, through which freedom gains objectivity. In a sense, freedom in Hegel's case consists in the individual's boundless blending in with the objective spirit of the world. See broader: G. W. F. Hegel, Wykłady z filozofii dziejów, transl. A. Zieleńczyk, Warszawa 2003, 60; S. Łojek, Hegel i Nietzsche wobec problemu polityczności, Wrocław 2002, 190-196; R. Kozłowski, Heglowska koncepcja państwa, in: Hegel a współczesność, ed. R. Kozłowski, Poznań 1997, 97.

35 Cf. Z. Krasnodębski, Większego cudu nie będzie, Kraków 2011, 145. This thesis may also be associated with a naturalistic understanding of religion. See broader: S. Sztajer, Racjonalność religii wobec niektórych współczesnych prób jej naturalizacji, in: O racjonalności w nauce i w życiu społecznym, eds. Z. Drozdowicz, Z. Melosik, S. Sztajer, Poznań 2009, 275.

36 Cf. P. Valadier, Nędza polityki i moc religii, transl. T. Żeleźnik, Warszawa 2010, 20-22. 
an objective reality to convince people of the virtues of social life and especially the important virtue of solidarity. He thought that there was such a thing as moral progress and that, in fact, it was heading towards ever greater solidarity. People become somehow inclined to minimize suffering and misery existing in the world. Here, solidarity fulfills the function that a conscience rooted in religion used to perform, without, however, appealing to a sense of guilt and responsibility, without invoking religious precepts. Rorty obviously offers neither epistemology (the correspondence between the intellect and reality) nor metaphysics, in which the search for meanings and values beyond the language game is carried out. In his view, morality is supported by literature (but not by the Bible), in which man can find social ideals. Above all solidarity, which, however, is not related to the search for the truth about oneself or to the objectivity of values. Solidarity in this sense means the empathic principle of reaching out to the unhappy ${ }^{37}$. On such assumptions it is possible to build a secular society without the need to cement it with religious inspirations and rations.

Let us ask, however, if such a perspective will transform social practices, politics, culture, education, relations, media into school of solidarity, concern for the common good, civic virtues, and thus fulfil the telos of man? How to give meaning and purpose to life without reference to supernatural motives? Can you trust reason, art or modern civilization? Sergio Quinzio, the Italian thinker, in his meditations on contemporary social disappointments, notes that modernity denies the news of the need for God and salvation, but that at the same time the thesis about the rebirth of the world through the progress of history, the development of science and technology, the social revolution is only an attempt to accomplish a pseudo-resurrection ${ }^{38}$.

Rorty emphasized that the true value of solidarity does not depend on where it comes from, but on how it is produced, and therefore, as is the case with Jürgen Habermas' theory of communication,

37 Cf. R. Rorty, Przygodność, ironia i solidarność, transl. W. J. Popowski, Warszawa 2009, 293-297.

38 See: S. Quinzio, Przegrana Boga, transl. M. Bielawski, Kraków - Dębica 2008, 88-89. 
the American thinker wants solidarity to be born as an act known and learned from literary texts ${ }^{39}$. The very conviction that the ideas of goodness, kindness, solidarity learned from literature will ensure proper social relations and will be permanently assimilated in the era of media and culture tabloidization is a reverie of academic intellectuals. Is there not, without references to God and "bad faith", without objective standards of justice, only a reference to pleasure, emotional preference or what is called "personal satisfaction"? Such recourse to emotions, without stating the reasons, can only generate views that change from hour to hour. The speaker, who is deprived of a permanent point of reference, and the listeners, who have only their own emotions, leave Rorty's beloved idea of solidarity to the mercy of whims ${ }^{40}$. Of course, Comte-Sponville sees the danger of nihilism - revolution of lawlessness and sloth, barbarism, contempt for values and duty, relations based on violence. All this can very quickly destroy social relations. But the French philosopher argues that this should be contrasted with the double wall of rationalism and humanism, whose foundations lie in the heritage of the West ${ }^{41}$.

It remains, however, unexplained why the language of secular stories, which is not stable enough to support the truth, should be strong enough to forge decency and solidarity as principles that are accepted by and unite different people. If we realize that language as a tool of expression can be used against the author's intentions, we are surprised to find that it has been granted the status of a means of achieving good - both in Rorty's vision and Habermas' theory. If solidarity is necessary to reduce the scale of human misery, what qualities and values associated with collective thinking would be able to induce people to do, as a group, what they are not willing to do, acting as individuals? Rorty says that we are simply motivated to make moral commitments by community solidarity, which transforms individual "I want" into

39 Cf. R. Rorty, Przygodność, ironia i solidarność, op. cit., 299.

40 Cf. P. Diggins, Iluzje pragmatyzmu, Modernizm oraz kryzys poznania i autorytetu, transl. M. Filipczuk, Warszawa 2010, 639; W. Buchner, Demokratyczna dewaluacja polityczności, Horyzonty Polityki 2(2011)2, 68.

41 Cf. A. Comte-Sponville, Duchowość ateistyczna, op. cit., 57-58. 
collective "we want" ${ }^{\text {" }}$. In the realm of solidarity, an invisible hand acts in some way like magic, transforming private vices and selfish aspirations into a collective virtuous quest for the common good. What is good for us is good for everyone. It is as if humanity has the ability to respond to the misfortunes of others through innate feelings such as sympathy, pity, and conscience. Of course, poststructuralism and postmodernism do not want to acknowledge that human nature has its innate inclinations as its foundation. Therefore, it is literature, not nature, that is to take over the tasks of morality. This peculiar and hopeful appeal is addressed to our imagination, not to our instincts. In the world of words, we are what our dictionaries are, and solidarity originates from acts of persuasion, from faith in the power of metaphor $^{43}$.

What's more, liberal democracy turns out to be incapable not only of raising the imperative of solidarity, but also of overcoming the disease of modernity - the emergence of anti-civil, mafia and exclusionary behaviour. It seems, says Eric Voegelin, that restoring proper order is only possible by recovering full reality, proper evaluation of its transcendent dimension, without ideological distortions. It simply means noticing the unquestionable role of religion in social life and the role of reason in assessing the situation of man and the world. We do not, therefore, live in a post-Christian, post-Philosophical, Neo-Pagan world, or in times of new myths that shape politics, but in the era of enormous de-culturization resulting from the deformation of reason, caused, paradoxically, by the secular process of destruction

42 Cf. R. Rorty, Przygodność, ironia i solidarność, op. cit., 292.

43 Before we allow the theses of the American pragmatist to seduce us, it should be noted that solidarity, instead of building morally, can brutally discriminate, as is the case of ethnic, religious, or racial solidarity and the "cleansing" that the massacres carried out in their name brought about. But interestingly, Rorty wants solidarity to function as a social reality, largely for the reasons why Adams reconstructed the image of the Virgin as an opportunity in the literary space - to value the cultivation of mercy and compassion. Both the philosopher and the historian want to convince us not of what is, but of what could be, as a product of literary imagination. Cf. J. P. Diggins, Iluzje pragmatyzmu. Modernizm oraz kryzys poznania i autorytetu, op. cit., 637. 
of religious narratives ${ }^{44}$. Can this deformation become a place of formation for new generations? This is an open question, but a positive answer is extremely risky, as its verification will no longer take place in theory, but in specific social relations and attitudes.

\section{CONCLUSIONS: THE REAL POWER OF RELIGION - INTERNAL TRANSFORMATION}

In my opinion, the thesis about the unquestionable and inalienable role of religion in public and political life is based on quite a simple but key observation. The atmosphere of social and political life is determined by the personal life of individuals of which the community is composed. This is well illustrated by the saying of Forster, which, at the beginning of the 20th century, was recalled by father Woroniecki: "das Sociale lebt vom persönnlichen - the whole value of social life depends on the personal values of individuals". Hence, religion does not so much formulate social morals (this can actually be done to some extent by culture or politics). This is its secondary task, but it is a necessary consequence of the first and foremost task of religion - to sanctify the souls of individuals. The moral success of today's secularized Christian societies is possible only through religion, understood not as a bond, but as a living relationship with God - found, known and beloved ${ }^{45}$.

John Gray expresses similar intuitions in different words. In his book Black Mass. Apocalyptic Religion and the Death of Utopia, he makes a very strong thesis that modern politics (politics subjected to the idea of great separation) is only a chapter in the great book of religious history. He argues that the idea that it is possible to build a wonderful world in which religion is only a private little space nurtured in the privacy of individual behaviour is a dangerous dream of idealist-utopians. It is necessary to accept, says Gray, the irreducible presence of religion in individual and social life, as well

44 Cf. E. Voegelin, The Gospel of Culture, in: The Collected Works of Eric Voegelin, vol. 12, Published Essays 1966-1985, ed. E. Sandoz, Louisiana State University Press, Baton Rouge 1990, 178.

45 See: J. Woroniecki, Kościół w oczach wiary, Szkoła Chrystusowa 13(1939)3, 153-154. 
as (which is difficult for the followers of secularization) political life. Religions, faiths and confessional beliefs are an ordinary part of the public sphere, and thus also at a higher level, of the political sphere. If only, the British thinker concludes, we take a rational and realistic approach to religion, no evil demons will spoil social relationships ${ }^{46}$.

When modern scholars excluded God and religion from political debate and later postmodern scholars deconstructed the true powers of human reason, it turned out that if there is no reference to something transcendent, the question of truth hangs in the air. We are thrown into a universe where any judgment about what is true or false, good or bad becomes unfounded because there is no objective measure which can be applied to the assessment of behavioral patterns. The inability to refer to the hierarchically ordered truth about reality has the vulnerability of man against the phantoms of his mind as one of its possible consequences - Czesław Miłosz wrote - Does the man involuntarily become an emanation of nothingness and nothingness consumes all their mental choices? Religion provides at least a meaningful world ${ }^{47}$. So I think Krasnodębski is right: if the project of a complete secularization of the public sphere or the internalization of religion so that its prerogatives would become immanent components of culture and politics and would be animated by them, it would mean the end of experiencing politics, as it has been understood from the beginning of the European ethos. What would remain would be administration, internal game of interest, or simple violence ${ }^{48}$. When the inner power of religion that animates the community dies, certain ideas and values become false, they become a source of corruption, they reveal themselves as illusory, fictitious $^{49}$. As a result, not only will there be no dialogue of cultures without

46 Cf. J. Gray, Black Mass: Apocalyptic Religion and the Death of Utopia, Farrar 2008, 33. The inconsistency of reason with the experience of transcendence is discussed by A. MacIntyre in the book God, Philosophy, Universities: A Selective History of the Catholic Philosophical Tradition, Rowman and Littlefield 2011.

47 Cf. C. Miłosz, O erozji, Tygodnik Powszechny 51-52(1998), 8.

48 Cf. Z. Krasnodębski, Większego cudu nie będzie, op. cit., 167.

49 Cf. J. P. Diggins, Iluzje pragmatyzmu, Modernizm oraz kryzys poznania i autorytetu, op. cit., 522. 
religion, but, above all, there will be no human reconciliation without this rationale, which, although it escapes positivist scrutiny, forms the basis of moral attitudes for many people. If there is no religion in its original rather than cultural form, what will constitute the power that binds social rations together?

In 1941, after the outbreak of the war in Europe and the disclosure of the bestiality of German Nazism, Mortimer J. Adler, an American philosopher from the University of Chicago, gave a controversial lecture entitled God and professors, in which he accused positivism, naturalism and pragmatism of nihilistic cruelty. He argued that the departure from the ethical reflection objectified in God as the guarantor of the concepts of good and evil, of fairness and wickedness, is due to the degradation of classical philosophical thinking, and especially of metaphysics, which is the only one capable of rationally justifying the existence of the Absolute Being. Without this, the pragmatic philosophy (postmodern, as we would say today) has no theoretical basis for pointing to inviolable values. There is no foothold to justify one's cultural, ethical and political theses. This philosophy has lost wisdom, which is the understanding of first principles and causes. ${ }^{50}$. Schooyans speaks directly of the threat posed by the totalitarian deviation of liberalism, which results in anarchism, obviously understood in a specific way. Anarchism as the social prevalence of individuals and the strongest groups, whose actions are not subject to universal legal jurisdiction, moreover, they even become the law. In this way, a kind of ethical oligarchical groups are revealed, to which other rules and other interpretations apply ${ }^{51}$. This obviously leads to a controversial conclusion - those who disregard religious principles will soon also cease to respect moral principles and then political agreements and obligations. If there is no significant authority on moral attitudes to

50 Cf. M. J. Adler, God and the Professors, in: Pragmatism and American culture, ed. G. Kennedy, Heath 1950, 67ff.

51 M. Schooyans, Totalitarne zagrożenie demokracji, transl. K. Deryło, Ethos 21-22(1993), 126. Similarly, Halik believes that the cultural and political victory of secularism carries the temptation to make secularism a "religion" and, consequently, an intolerant and totalitarian religion. Cf. T. Halik, Europa pomiędzy laickością a chrześcijaństwem, op. cit., 130. 
human behavior, as well then the community needs soldiers and prisons $^{52}$. However, this would never be what postmodern thinkers themselves would want, as it would condemn the intellectual elite above all to the loss of the cultural goods for which generations have worked. The social death of religion and the replacement of its strength by the power of political and cultural reasons would then show its monstrous face - humanism without divinity.

\section{BIBLIOGRAPHY}

Adler M. J., God and the Professors, in: Pragmatism and American culture, ed. G. Kennedy, Heath 1950.

Buchner, W. Demokratyczna derwaluacja polityczności, Horyzonty Polityki 2(2011)2, 67-87.

Burdziej S., Socjologia postsekularna?, Studia Socjologiczne 197(2010)2, 89-107. Casanova J., Deprywatyzacja religii, in: Socjologia religii Antologia tekstów, ed. W. Piwowarski, Kraków 1998.

Comte-Sponville A., Duchowoś́ ateistyczna. Wprowadzenie do duchowości bez Boga, transl. E. Aduszkiewicz, Warszawa 2011.

Delbanco A., The Real American Dream: A Meditation on Hope, Harvard University Press 2000.

Dewey J., Philosophy and Democracy, in: The Middle Works of John Dewey 1899-1924, vol. 11 (1918-1919), ed.J. A. Boydston, Southem Illinois University Press 1988.

Diggins P., Iluzje pragmatyzmu. Modernizm oraz kryzys poznania i autorytetu, transl. M. Filipczuk, Warszawa 2010.

Dobbelaere K., Sekularyzacja. Trzy poziomy analizy, transl. R. Babińska, Kraków 2008.

Dominiak Ł., Cztery koncepcje zoon politikon. Uwagi dotyczace problematyczności politycznej natury cztowieka, Horyzonty Polityki 1(2010)2, 91-109.

Durkheim E., Elementarne formy życia religijnego. System totemiczny w Australii, transl. A. Zadrożyńska, Warszawa 1990.

Eagleton T., Rozum, wiara i rewolucja. Refleksje nad debatq o Bogu, transl. W. Usakiewicz, Kraków 2010.

52 See: K. J. Schipperges, Religia a zeświecczone społeczeństwo. Instrumentalizacja religii w nowożytnych systemach władzy politycznej, op. cit., 84. 
Gray J., Black Mass: Apocalyptic Religion and the Death of Utopia, Farrar 2008.

Grotius H., Trzy ksiegi o prawie wojny i pokoju w których znajduja wyjaśnienie prawo natury i prawo narodów a także gtówne zasady prawa publicznego, transl. R. Bierzanek, Warszawa 1957.

Habermas J., Faith and Knowledge, in: Idem, The Future of Human Nature, Cambridge 2003.

Habermas J., Ratzinger J., The Dialectics of Secularization. On Rison and Religion, San Francisco 2005.

Halik T., Europa pomiędzy laickościq a chrześcijaństwem, Więź (2011)2-3, 125-132. Hegel G. W. F., Wyktady z filozofii dziejów, transl. A. Zieleńczyk, Warszawa 2003. Jankowicz G., Nowoczesne misteria pañstwa, Tygodnik Powszechny 48(2009), 40.

Kozłowski R., Heglowska koncepcja państwa, in: Hegel a wspótczesność, ed. R. Kozłowski, Poznań 1997.

Krasnodębski Z., Większego cudu nie będzie, Kraków 2011.

Król M., Filozofia polityczna, Kraków 2008.

Lilla M., Bezsilny Bóg. Religia, polityka i nowoczesny Zachód, transl. J. Mikos, Warszawa 2009.

Eojek S., Hegel i Nietzsche wobec problemu polityczności, Wrocław 2002.

MacIntyre A., God, Philosophy, Universities: A Selective History of the Catholic Philosophical Tradition, Rowman and Littlefield 2011.

Marczewska-Rytko M., Religia i polityka w globalizującym się świecie, Lublin 2010.

Mariański J., Religia w spoteczeństwie ponowoczesnym, Warszawa 2010.

Michel P., Polityka i religia. Wielka przemiana, transl. B. Czarnowska, Kraków 2000. Miłosz C., O erozji, Tygodnik Powszechny 51-52(1998), 8.

Moltmann J., Theology of hope: on the ground and the implications of a Christian eschatology, transl. J. W. Leitch, London 2002.

Quinzio S., Przegrana Boga, transl. M. Bielawski, Kraków - Dębica 2008.

Ritzer G., Magiczny świat konsumpcji, transl. L. Stawowy, Warszawa 2009.

Rorty R., Filozofia a zwierciadto natury, transl. M. Szczubiałka, Warszawa 1994.

Rorty R., Konsekwencje pragmatyzmu. Eseje z lat 1972-1980, transl. C. Karkowski, Warszawa 1988.

Rorty R., Przygodnośc, ironia i solidarność, transl. W. J. Popowski, Warszawa 2009.

Rorty R., Religion in the Public Square. A Reconsideration, Journal of Religious Ethics 31(2003), 141-149. 
Schipperges K. J., Religia a zeświecczone spoteczeństwo. Instrumentalizacja religii w nowożytnych systemach wtadzy politycznej, transl. B. Floriańczyk, Communio 138(2003)6, 79-102.

Schooyans M., Totalitarne zagrożenie demokracji, transl. K. Deryło, Ethos 2122(1993), 123-130.

Sochoń J., Religia jako odpowiedz, Warszawa 2008.

Sztajer S., Racjonalność religii wobec niektórych wspótczesnych prób jej naturalizacji, in: O racjonalności w nauce i w życiu spotecznym, eds. Z. Drozdowicz, Z. Melosik, S. Sztajer, Poznań 2009.

Szulakiewicz M., Religie i religijnośc we wspótczesnej kulturze, in: Religie i religijność we wspótczesnym świecie. III Międzynarodowy Kongres Religioznawczy, ed. M. Szulakiewicz, Torun 2011.

Valadier P., Nędza polityki i moc religii, transl. T. Żeleźnik, Warszawa 2010.

Vattimo G., After the Christianity, Columbia University Press 2002.

Voegelin E., The Gospel of Culture, in: The Collected Works of Eric Voegelin, vol. 12, Published Essays 1966-1985, ed. E. Sandoz, Louisiana State University Press, Baton Rouge 1990.

Wallace R. A., Emile Durkheim and the Civil Religion Concept, Review of Religious Research 18(1977), 287-290.

Weber M., Polityka jako zawód i powotanie, transl. A. Kopacki, P. Dybel, Warszawa - Kraków 1998.

Weiler J. H. H., Chrześcijańska Europa. Konstytucyjny imperializm czy wielokulturowość, Poznań 2003.

Woroniecki J., Kościót w oczach wiary, Szkoła Chrystusowa 13(1939)3, 147-162.

Wróbel S., Kto się boi liberalnej religii obywatelskiej?, Znak 671(2011)4, 43-50.

Jacek Grzybowski

Cardinal Stefan Wyszyński University in Warsaw, Institute of Philosophy, Poland

ORCID: https://orcid.org/0000-0001-7814-6825

j.grzybowski@uksw.edu.pl

DOI: $10.21697 /$ spch.2020.56.S2.12 